\title{
Social Development in the Urban Informal Sector: Study on Street Vendors in Pasar Minggu Jakarta
}

\author{
Cucu Nurhayati \\ Department of Sociology, Faculty of Social and Political Sciences UIN Jakarta, Indonesia \\ Cucu.nurhayati@uinjkt.ac.id
}

\begin{abstract}
Economic development which excluded the quality of human development has resulted in social inequality. The concept of social development comprises the societal and holistic aims to improve the quality of life. This research aims to illustrate the concept of social development based on the structure, culture and social processes which uses the concept developed by Wirutomo as the reference. This study uses qualitative and quantitative research method to facilitate an understanding towards the construction of the social development as well as the real condition of the street vendors in Jakarta. The result indicates the development of a social structure which includes the structural setting and instruments in the social development of the street vendors which cannot be realized in the form of a practical policy to improve life street vendors' life quality. Quantitively, the development shows a positive trend which is in accordance with Jakarta's mission to be the city for the people of all cultures. However, the change of behavior especially of the local officers, such as Satpol PP and government's official, is needed to create a more polite and persuasive method for the development of the street vendors. This study recognizes that the stakeholders consisted of the government of Jakarta, UPB Pasar Minggu and the street vendors, were still unable to establish a satisfactory interaction and communication for the improvement of the social development. This study concluded that the effort to manage and relocate the street vendors are still on it way to meet the inclusive development goal.
\end{abstract}

Keywords- Social development, informal sector, structure, culture and process.

\section{INTRODUCTION}

The concept of development that only prioritizes economic development has resulted in poverty, unemployment, and imbalance income distribution. It is the time to no longer put economic development as the primary focus. Instead, we should focus more on the development of human quality as the social capital. Social development is a concept that concerns on the societal and holistic development that aims to improve the quality of life of the community. Social development in urban areas becomes an interesting thing to study, because the city is structurally and culturally becomes a gathering place for people from various regions with various interests. Uneven development between rural areas and urban areas encourages people to migrate to cities even though they are not equipped with an adequate set of skill and capability to survive the urban living competition. The ratio of formal sector employment results in the flow of workers in the informal sector. The informal sector of street vendors in urban areas has an important role for urban poor people with limited capital and skills. The informal sector is a choice of employment with the marginalization of rural agriculture and the urban economic safety valve. The street vendors (or in Indonesia knwn as PKL) is able to find their economic safety and further contribute to the city economic development. PKL becomes an option for the community because it does not require much effort and can be easily accessed by many. Becoming a PKL, one does not need to have a special skill and huge capital. However, the presence of street vendors in urban areas is often confronted by the security personnel named Satpoll PP whose responsibility is control and relocate the PKL. Thus, urban studies using social development concepts aimed at creating an inclusive society would be interesting if linked to the urban informal economy sector, in this case, the street vendors.

\section{THEORETICAL FRAMEWORK}

\section{The informal sector}

Some experts, as quoted by Dewantari [1] put forward some opinions about the informal sector in economy. Hart, a economic anthropologists introduces the concept of the informal economy through the division of income opportunities. He mentions that there are three division, namely formal, informal and informal income opportunities. A Dutch scholar, Julius Herman Boeke, distinguishes economic activities into the capitalist principles (represented by the company) and orientalist economic activity. Fujimaki explains that economic activities can be categorized into four activities, which are: formal, informal, illegal and criminal. This category sometimes comes in large or small companies. Illegal activity occurs when using a place that is not built specifically for economic activity. Smugglers often do these illegal and criminal activities. Hans Dieter Evers and Rudiger Kaff highlight the informal sector as a survival strategy for people living in urban areas. Living in a city without being listed or excluded in the state balance sheet makes the informal sector considered as a shadow economy that means beyond the reach of government policy in power or inversely proportional to the formal sector. Because the informal sector includes "shadow 
economy," it is often positioned as opponents of development for the state.

\section{Social Development}

The social development referred to in this research is development based on structural elements, culture, and process. Understanding these three elements refers to the concept developed by Wirutomo [2]. The social structure is a pattern of relationships between social groups that imply the coercive, meaningful, and limiting the power that is dominant over the powerless actors. Social structures relate to policies or regulations of laws and regulations issued by the government. The second element of social development is culture. Culture is defined as a system of values, norms, beliefs, and customs, and traditions, internalized by individuals or communities, to have the power to shape patterns of behavior and attitudes of community members. Thus this cultural change requires a structure in the form of policy, applied by the government. The third element of social development is the social process. The social process is an activity done by individuals or groups in daily interaction. By this interaction people can build a network, community, and solidarity. The interaction and dialogue process can establish itself. Daily activities carried out are a process to form coordination and concentration together so as to make a change. This study uses qualitative and quantitative research methods to facilitate the forming stage the of social development as well as to understand the meaning of the reality of street vendors

\section{STRUCTURAL DEVELOPMENT, CULTURE, AND SOCIAL PROCESSES}

The development of social structure consists of the component quality improvement of setting structure, structural of instrument, improvement of demography structure and institutionalization [3]. Increasing the quality of community life inclusively in structural development aims to improve structural setting of differentiation and social stratification with support from structural instruments. This development is expected to have a cross-sector impact covering various fields, economically, socially and culturally. Economically, street vendors can increase their income; so they can socially improve access to education and health. Structurally the concept of social development can be used to measure the structural setting or efforts undertaken by the government in reducing social stratification in society. The success of the structural setting of course must be supported by the structural instruments which are the government policy in assisting street vendors in the form of policies or regulations. This includes a real budget disbursement policy in reducing the sharp social stratification between the formal and informal sectors.

Cultural development must be rooted in local traditions that can be readily accepted by the community. The development of social processes can produce different results depending on the processes applicable in each region. The better the process, the more institutionalization policies and internalization of the prevailing culture. This process is an interaction, communication, negotiation undertaken by the public through formal or informal forums in discussing, discussing, dealing with a new rule or policy imposed by the government. Habermas's concept of public space [4] has an important role as a process of interaction and communication in society to reach an agreement between the government and street vendors in realizing social development. With the closed public space to interact and communicate the social process will not happen. The realization of social processes can give rise to internalization and institutionalization of new cultures and rules in society.

\section{Social development for Informal Sector}

Social development in DKI Jakarta, in general, is still controlled by the "informal structure" of capitalist enterprise and added by the hegemony of capitalist culture which colonizes the culture of the people [5]. This condition becomes one of the difficult aspects of creating a social development of urban informal sector inclusiveness. Production of vegetables, fruits and clothing are more attractive when supported by the packaging of capitalist companies that able to distribute the product in malls, supermarkets or modern markets that instill a culture of hedonism and high consumptives. With the service of facilities that pamper the consumer, hegemony of capitalist culture has attracted market share to choose modern market rather than the traditional market despite the growth of informal sector's street vendors. This is where it needs attention from the government. If the power of private companies dominates our cultural life, with the structural strength that is granting permission from the government. So, by itself, the culture will dominate the life of the community with more fun shopping in the mall than shopping on street vendors. Then the concept of Lefebvre [6] on the growth of the city containing contradictions proved to have a strong strength to hinder the idea of social development. In the context of urban space with the occurrence of conflicts over land tenure, the ruler prefers mall construction rather than development and the provision of facilities to street vendors. The contradiction of perceived space with conceived space occurs when urban space as a reality that becomes the domain of urban planners has led to irregularities or mismatches between development and urban planning. This is where the need for a firm attitude of the city authorities to provide a decent place for street vendors by providing development planning that favors the people. If the government does not have the firmness in building the economy of a small society then in itself will give birth to a contradiction between the repressions of space with the representation of space. Under this condition, when street hawkers are not in accordance with what is expected by space planners will be removed from the environment. Street vendors are always excluded and considered a cause of social 
clutter without considering its role as the urban poor's economic rescue valve. While the contradiction between fixed capital and variable capital occurs when urban space is predicted to be a generator or preserver of capital surplus values, capitalists still have a substantial role in the growth of the city's economy, leaving behind the urban slums of the city the small profit they gain.

In the case of a five-time trader, there must be an agent who is able to change the policy towards street vendors. The strength of the structure remains dominant in this case, although culture also plays a role in changes in the behavior of street vendors and street vendors. But without the reform of bureaucracy, it is difficult for policy changes to street vendors. The existence of malls in big cities such as Jakarta as a symbol of capitalism is a thing that is so visible. Thus the ruler in this case the government to advance the street vendors and intend to make them "merchants" must be followed by the empowerment of street vendors. However, if the ruler still "perpetuates" the informal capitalist structure followed by the hegemony of capitalist culture in society, then the street vendors will continue to be second-class marginalized economies.

The concept of social development must be followed by the strength of the agent or individual who has the power to change the situation. This concept does not place the strength of agent's role clearly in structural elements, cultures, and processes. Then, when agents or individuals have a strong role, what will be the role of the state? The concept of social development still requires some studies to be applied in the development of the community entirely inclusive, in order to improve the quality of life of the community.

\section{The reality of social development}

Social development in addition to having a role in community empowerment also plays a role to realize the agreement and collectivity of activities to improve the quality of life better. Structure, culture, and process are integral elements, and intersect which creates forms of social development. The social development of street vendors in Jakarta within the framework towards inclusive street vendors is still at the stage of the process. In the aspect of empowerment of permanent kiosk facilities provided by the government has not been sufficient, and the rules of general trading have not been implemented properly. Collectively, the participation of street vendors in creating communication space among fellow street vendors, in the form of paguyuban as a means for interaction and deliberation has not developed significantly. In realizing the inclusive development of street vendors, there are at least three things that become intermediate variables, namely: the existence of clear, decisive leadership, rules or policy structures, as well as changes in the behavior of more cultured apparatus to generate intensive and more persuasive communication.

\section{REFERENCE}

[1] Dwianto Dewantari,. Raphaella (2008)., Unchanging Fortunes of Jakarta Informal Sector Workers dalam Globalization, Minorities and Civil Society Prespectives from Asian and Western Cities. Japan: Stratification and Inquality Series: The center for the Study of Social Stratification and Inequality, Tohoku University, Japan volume 8.

[2] Wirutomo, Paulus. (2011). Social Development Policies on Informal Sector in Solo, International Journal of Administrative Science \& Organization, Volume 18, Number 2, May 2011. ISSN 0854 - 3844, Accredited by DIKTI Kemendiknas RI No : 64a/DIKTI/Kep/2010

[3] Wirutomo, Paulus. (2012). Sosiologi untuk Jakarta: Menuju Pembangunan Sosial-Budaya. Jakarta: Lembaga Pemberdayaan Masyarakat Jakarta (LPMJ).

[4] Habermas, Jugen. (1989), the Structural Transformation of the Public Sphere: an Inquiry into a Category of Bourjuis Society.United States Amerika: DEKR Corporation.

[6] Wirutomo, Paulus. (2012). Sosiologi untuk Jakarta: Menuju Pembangunan Sosial-Budaya. Jakarta: Lembaga Pemberdayaan Masyarakat Jakarta (LPMJ).

[7] Lefebvre, Henri., (2007), Donald Nicholson Smith (terj)., The Production of Space, UK: Blackwell Publishing. 